\title{
Reducibility as a prognosis factor of progression in idiopathic scoliosis
}

\author{
Blanca Palomino*, Alicia Villareal, Lorenzo Jiménez, Avelino Ferrero, José Acosta \\ From 8th International Conference on Conservative Management of Spinal Deformities and SOSORT 2011 \\ Annual Meeting \\ Barcelona, Spain. 19-21 May 2011
}

\section{Background}

Scoliosis is a disease that develops during growth and knowledge of scalability is essential for making treatment decisions. Of the many factors analyzed, are evidence of sex, topography, menarche, age, rapid growth spurt the magnitude of the curve, Risser 0 - 1 and the imbalance of occipital axis $>10 \mathrm{~mm}$. The degree of reductibility or flexibility is also seen as a predictor of progression during grotw. In this line we have wanted to study whether there is correlation between the initial reduction with cast plaster and outcome in the medium and long term.

\section{Matherials and methods}

This is a retrospective study of 50 patients in the service of Physical Medicine and Rehabilitation of our hospital, which have required orthopedic reduction with a cast and subsequent follow-upcorset. Were analyzed for age, sex, topography of the curve, initial angle value, correction after the cast, final angular value, duration.

\section{Results}

Of the initial sample in $35^{\circ}$ of cases whose initial correction with the cast was less than $10 \%$ had a progression more than $6^{\circ}$ at final follow up (8 years), and $65 \%$ of the sample progression did not exceed initial angular value on more than $6^{\circ}$. Cases where the cast correction exceeded $10 \%$ at follow-up (8 years), $6 \%$ exceeded 6 , and $94 \%$ remained stable compared to the initial angular value, not to exceed $6^{\circ}$.

\section{Conclusions}

The initial reducibility factor by treating orthopedic cast, you can be aware of how predictive of long-term outcome.

Hospital Ramón y Cajal, Madrid, Spain
Published: 27 January 2012

doi:10.1186/1748-7161-7-S1-P19

Cite this article as: Palomino et al:: Reducibility as a prognosis factor of progression in idiopathic scoliosis. Scoliosis 2012 7(Suppl 1):P19.
Submit your next manuscript to BioMed Central and take full advantage of:

- Convenient online submission

- Thorough peer review

- No space constraints or color figure charges

- Immediate publication on acceptance

- Inclusion in PubMed, CAS, Scopus and Google Scholar

- Research which is freely available for redistribution
C Biomed Central

\section{() Biomed Central}

(c) 2012 Palomino et al; licensee BioMed Central Ltd. This is an open access article distributed under the terms of the Creative Commons Attribution License (http://creativecommons.org/licenses/by/2.0), which permits unrestricted use, distribution, and reproduction in any medium, provided the original work is properly cited. 